\title{
Sour milk beverage preparation technology
}

\author{
Zh.A. Vlasova*, V.A. Gasieva, P.N. Semenov, L.Sh. Cheldieva, and E.A. Kruglova \\ FSBEI HE Gorsky GAU, Vladikavkaz, North Ossetia-Alania, Russian Federation
}

\begin{abstract}
In order to expand the range of dairy products for the elderly, a technology has been developed for preparing a fermented milk drink with stevia, using a combined starter culture from kefir fungi, bulgarian bacillus, thermophilic streptococcus and bifidobacteria. During the research, modern standard methods were used. The research was carried out in the laboratory of the Research Institute of Agroecology of the Gorsk State Agrarian University, in the laboratory of food products of the commodity-technological faculty of the Gorsky State Agrarian University, in the Scientific Laboratory of Feed and Metabolism of the Stavropol State Agrarian University. In laboratory conditions, the quality of milk and fermented milk drink was determined. The organoleptic, physicochemical, microbiological indicators of the quality of milk and milk drink, the amino acid composition of proteins, the content of toxic elements, and nutritional value have been investigated. During our research, we found that the quality of the used pasteurized cow's milk meets the requirements of the standard and TR CU. During laboratory studies, it was found that the quality indicators of the fermented milk drink are within the requirements of the current NTD. According to economic calculations, the production of this product is profitable.
\end{abstract}

\section{Introduction}

The number of elderly people in the world is constantly growing. Elderly people are advised to introduce up to $30 \%$ of proteins into the diet from dairy products. Fermented milk products are especially useful - kefir, yogurt, acidophilus, etc. Their positive effect is mainly associated with the presence of lactic acid microorganisms that prevent the development of putrefactive processes in the intestine [1].

The relevance of the chosen topic is due to the fact that at present, functional fermented milk drinks are in increasing demand among elderly and senile people, but the range of these drinks is small.

The technology of a fermented milk drink with stevia based on a combined ferment is proposed, which determines the scientific novelty of the work.

The quality of milk has been repeatedly determined in our republic and other republics of the country, which is reflected in the research materials of scientists $[2,3,4,5]$.

The Research Institute of Biotechnology of the Gorsky State Agrarian University has a large collection of microorganisms deposited in VKPM, which are used in the development

\footnotetext{
*Corresponding author: zhanna.vlasova.58@mail.ru
} 
of new types of fermented milk products, which is reflected in the scientific research of the university employees $[6,7]$.

\section{Materials and methods for research}

The objects of research were pasteurized cow milk, milk drink, ferment of pure cultures of lactobacilli, prebiotic. Stevia extract was used as a prebiotic.

Research methods were selected in accordance with the determined indicators, mainly using standard research methods.

In the study of physicochemical parameters, the mass fraction of fat was determined by the Gerber acid method, acidity by titration, density with a lactodensimeter, purity group by filtration and comparison with a standard, mass fraction of dry matter by drying at a constant temperature in a drying oven, mass fraction of protein by the Kjeldahl method and using ultrasound on the device "Klever-2", the temperature with a thermometer, the presence of the peroxidase enzyme by reaction with potassium iodide starch.

In the study of microbiological indicators, the presence of bacteria of the E. coli group was determined by inoculation in Kessler medium, the number of mesophilic aerobic and facultative anaerobic microorganisms inoculation in dense nutrient agar, the number of lactic acid microorganisms inoculation in sterile milk and solid nutrient media, identification of bacteria of the genus Salmonella with identification on the Endo environment.

The presence and amount of toxic elements was determined using the atomic absorption method.

For the quantitative determination of the amino acid content in the samples of drinking milk and milk drinks, an AAA 400 amino acid analyzer of the Czech company INGOS was used; the research was carried out in the Scientific Laboratory of Feed and Metabolism of the Stavropol State Agrarian University.

The main raw material for the production of dairy drinks is cow's milk. Requirements for its quality are established in GOST 31450-2013 "Drinking milk. Technical conditions ", TR CU 021/2011" Technical regulations of the Customs Union. On food safety ", TR CU 033/2013“ "Technical regulations of the Customs Union. On the safety of milk and dairy products " $[8,9,10]$.

The results of the obtained experimental data were processed mathematically using a program from the current Microsoft office package.

\section{Research results and their discussion}

Let us consider the technological schemes for the production of fermented milk drinks in the factory for their implementation in the retail network and / or in the public catering network, and the schemes for the manufacture and sale in the conditions of public catering enterprises.

Let's move on to the technological scheme for the production of fermented milk drinks in industrial enterprises using reservoir and thermostatic methods. The technological process of production consists of the following operations: reception of milk in terms of quantity and quality; fat normalization of milk; pasteurization and homogenization of milk (pre-purified milk is homogenized at a pressure of $12,5 \pm 2,5 \mathrm{MPa}$ and a temperature of 45 $55{ }^{\circ} \mathrm{C}$, pasteurized in a pasteurization-cooling unit at a temperature of $74-78{ }^{\circ} \mathrm{C}$ with a short-term exposure of 20 seconds); cooling to the fermentation temperature; adding starter culture and fermenting milk in the tank; cooling and adding the necessary additives, mixing 
and filling in the tank method; aftercooling, maturation and storage of the packaged product.

With the thermostatic method, the fermented mixture with the necessary additives must be quickly poured into containers and sealed within 40 minutes. Then send for ripening in a thermostatic chamber at a temperature of $37^{\circ} \mathrm{C}$. After the end of fermentation, the product is transported to the refrigerator, where it is cooled, matured and stored until sale.

Let us consider the scheme developed by us for the production of fermented milk drinks in the conditions of public catering establishments.

In the manufacture of fermented milk drinks, thermally processed drinking milk is mainly used, which is purchased in trade enterprises. You can pasteurize or boil raw milk in a catering environment. Heat treated milk must be brought to the fermentation temperature.

It is recommended to manufacture the product by the thermostatic method, which will increase its microbiological purity, which is determined by the presence of pathogenic and opportunistic microorganisms.

In milk $\left(\mathrm{t}=37^{\circ} \mathrm{C}\right)$, poured into glass jars, add a combined starter culture consisting of kefir starter culture and bio-leaven (bifidobacteria, thermophilic streptococcus, bulgarian bacillus), mix well, seal the container, leave it warm for fermentation. At the end of the fermentation, the product is cooled and only then stirred.

If you have a yogurt maker or a VAR bath, you can make a product in them.

After the end of fermentation and maturation in a refrigerator, the drink is cooled to a temperature of $17-18{ }^{\circ} \mathrm{C}$, stevia extract is added and mixed.

To prepare stevia extract, dry stevioside in an amount of $1 \mathrm{~g}$ is dissolved in $100 \mathrm{~cm}^{3}$ of hot water, and allowed to brew for 30 minutes, filtered, and cooled.

The finished fermented milk drink must be stored in a refrigerator, or immediately sold. Serve in glasses.

When carrying out organoleptic studies of pasteurized milk, the consistency, color, taste and smell were determined. The investigated drinking milk had a clean smell and taste characteristic of pasteurized milk, a homogeneous, non-viscous liquid of white color in consistency. Based on the results of the organoleptic assessment carried out, it can be said that the milk used for the preparation of milk drinks met the requirements of the standard.

In the studied drinking milk, the mass fraction of protein was $3.1 \%$, SNF $-8.27 \%$, mass fraction of fat $-2.62 \%$, acidity $-16^{\circ} \mathrm{T}$, density $-1.0295 \mathrm{~g} / \mathrm{cm}^{3}$, temperature $-6{ }^{\circ} \mathrm{C}$, purity group -1 , which meets the requirements of GOST 31450-2013.

Microbiological examination revealed that no BGKP were found in $0.01 \mathrm{~cm}^{3}$ of pasteurized milk. The amount of MAFanM was $5 \cdot 10^{4} \mathrm{CFU} / \mathrm{g}$. There were no pathogenic microorganisms, including salmonella in $25 \mathrm{~cm}^{3}$ of milk. Therefore, pasteurized milk is safe for health, the indicators are within the limits established by the NTD (normative technical documentation).

When assessing the safety indicators of the studied pasteurized milk, we found that there were no toxic elements (lead, arsenic, cadmium, mercury).

The developed recipe for a fermented milk drink with stevia for heroic nutrition is shown in table 1.

Table 1. Recipe for fermented milk drink with stevia.

\begin{tabular}{|l|c|c|}
\hline Component name & For a glass of drink & For $1 \mathrm{dm}^{3}$ of drink \\
\hline Drinking milk & $175 \mathrm{~cm}^{3}$ & $795 \mathrm{~cm}^{3}$ \\
\hline Kefir starter culture & $10 \mathrm{~cm}^{3}$ & $45 \mathrm{~cm}^{3}$ \\
\hline Bio-leaven & $18 \mathrm{~cm}^{3}$ & $82 \mathrm{~cm}^{3}$ \\
\hline Stevia extract & $17 \mathrm{~cm}^{3}$ & $78 \mathrm{~cm}^{3}$ \\
\hline Total drink & $220 \mathrm{~cm}^{3}$ & $1000 \mathrm{~cm}^{3}$ \\
\hline
\end{tabular}


In the finished drink, the nutritional value, quality indicators, and amino acid composition were determined.

Table 2.Nutritional value of fermented milk drink with stevia.

\begin{tabular}{|l|c|c|}
\hline Basic nutrients & Content in $100 \mathrm{~g}$ of product, $\mathrm{g}$ & Energy value, kcal \\
\hline Fats & 2.25 & 20.25 \\
\hline Protein & 2.78 & 11.12 \\
\hline Carbohydrates & 4.20 & 16.80 \\
\hline Total EC $100 \mathrm{~g}$ of drink & & 48.17 \\
\hline
\end{tabular}

According to the data given in table 2, it can be seen that the fermented milk drink contains all the necessary basic substances.

Table 3.The results of evaluating the organoleptic characteristics of a fermented milk drink with stevia.

\begin{tabular}{|l|l|}
\hline Indicator name & \multicolumn{1}{|c|}{ Research results } \\
\hline Appearance and consistency & $\begin{array}{l}\text { Homogeneous, moderately viscous, thick, with an } \\
\text { undisturbed clot }\end{array}$ \\
\hline Taste and smell & $\begin{array}{l}\text { Fermented milk, pleasant, not sour taste and smell. The } \\
\text { taste is sweet, without off-flavors }\end{array}$ \\
\hline Colour & White, uniform throughout the product \\
\hline
\end{tabular}

As a result of the studies, it was found that the organoleptic characteristics of the fermented milk drink with stevia were of good quality.

Table 4. The results of determining the physicochemical parameters of a fermented milk drink with stevia.

\begin{tabular}{|l|c|}
\hline \multicolumn{1}{|c|}{ Indicator name } & Research results \\
\hline Acidity, ${ }^{\circ} \mathrm{T}$ & 60 \\
\hline Mass fraction of dry substances, $\%$ & 9.94 \\
\hline SOMO, $\%$ & 7.69 \\
\hline Mass fraction of fat, $\%$ & 2.25 \\
\hline Mass fraction of protein, $\%$ & 2.78 \\
\hline Density, $\mathrm{g} / \mathrm{cm}^{3}$ & 1.02713 \\
\hline Peroxidase & Absent \\
\hline Temperature, ${ }^{\circ} \mathrm{C}$ & 4 \\
\hline
\end{tabular}

Considering the data given in table 4, we can say that this product meets the requirements for kefir GOST 31454 [11] and fermented milk products enriched with bifidobacteria GOST 33491 [12].

Table 5. Results of studies of microbiological indicators of fermented milk drink with stevia.

\begin{tabular}{|l|c|}
\hline \multicolumn{1}{|c|}{ Indicator name } & Research results \\
\hline Escherichia coli bacteria in $0,01 \mathrm{~cm}^{3}$ of the product & Not detected \\
\hline The number of lactic acid streptococci and bacilli, CFU/ $\mathrm{cm}^{3}$ & $1.2 \cdot 10^{7}$ \\
\hline $\begin{array}{l}\text { Pathogenic microorganisms, incl. salmonella in } 25 \mathrm{~cm}^{3} \text { of } \\
\text { product }\end{array}$ & Not detected \\
\hline
\end{tabular}

According to the results of studies of the microbiological parameters of a fermented milk drink with stevia, it can be concluded that this product is safe for humans, since BGKP and pathogenic microorganisms were not detected, the number of lactic acid microorganisms is quite high (at least 10 million CFU in $1 \mathrm{~cm}^{3}$ ), which meets the requirements, established in TR CU 033/2013. 
Table 6. Results of determination of toxic elements in $100 \mathrm{~cm}^{3}$ of fermented milk drink with stevia.

\begin{tabular}{|l|c|}
\hline \multicolumn{1}{|c|}{ Name of the toxic element } & Research results \\
\hline Arsenic & Not found \\
\hline Lead & Not found \\
\hline Cadmium & Not found \\
\hline Mercury & Not found \\
\hline
\end{tabular}

According to the results of the studies carried out to determine the presence and amount of toxic elements in the fermented milk drink with stevia for the dietary diet, it was established that arsenic, lead, cadium and mercury were not detected, the product is harmless to humans.

Data for determining the content of amino acids in the product are given in table 7 .

Table 7. Content of essential amino acids in fermented milk drink with stevia.

\begin{tabular}{|l|c|c|c|}
\hline Aminoacid name & $\begin{array}{l}\text { Essential amino acid } \\
\text { content, g per 100 g of } \\
\text { product }\end{array}$ & $\begin{array}{c}\text { Essential amino } \\
\text { acid content, } \\
\text { in 100 g of protein }\end{array}$ & $\begin{array}{c}\text { The content of } \\
\text { essential amino } \\
\text { acids in standard } \\
\text { protein (FAO / } \\
\text { WHO), g per 100 g } \\
\text { of protein }\end{array}$ \\
\hline Isoleucine & 0.154 & 5.54 & 3.0 \\
\hline Leucine & 0.298 & 10.72 & 5.9 \\
\hline Lysine & 0.247 & 8.89 & 4.5 \\
\hline Methionine & 0.081 & 2.91 & 1.6 \\
\hline $\begin{array}{l}\text { Phenylalanine }+ \\
\text { Tyrosine }\end{array}$ & 0.295 & 10.61 & 3.8 \\
\hline Threonine & 0.122 & 4.39 & 2.3 \\
\hline Valine & 0.198 & 7.12 & 3.9 \\
\hline Histidine & 0.089 & 3.20 & 1.5 \\
\hline
\end{tabular}

When determining the amino acid speed of a fermented milk drink with stevia, it was found that this drink has high performance. The rate of essential amino acids is arranged in descending order as follows: phenylalanine + tyrosine $-279.2 \%$; histidine $-213.3 \%$; lysine $-197.6 \%$; threonine $-190.9 \%$; isoleucine $-184.7 \%$; valine $-182.6 \%$; methionine $-181.9 \%$; leucine $-181.7 \%$.

As a result of the studies, it was found that a fermented milk drink with stevia can be stored for 5 days at a temperature of $4 \pm 2{ }^{\circ} \mathrm{C}$.

Table 8. Calculation card for fermented milk drink with stevia.

\begin{tabular}{|c|l|c|c|c|}
\hline $\begin{array}{l}\text { Order } \\
\text { number }\end{array}$ & Name of raw materials & $\begin{array}{l}\text { Raw material rate } \\
\text { for 1 portion, } \mathrm{dm}^{3}\end{array}$ & Unit price, rub. & $\begin{array}{c}\text { Amount, } \\
\text { rub. }\end{array}$ \\
\hline 1 & Milk & 0.175 & 60 & 10.50 \\
\hline 2 & Kefir starter culture & 0.010 & 70 & 0.70 \\
\hline 3 & Bio-leaven & 0.018 & 90 & 1.62 \\
\hline 4 & Stevia extract & 0.017 & 100 & 1.7 \\
\hline The total cost of the raw material set, rub. & 14.52 \\
\hline \multicolumn{2}{|l|}{ Margin 170 \%, rub. } & 10.16 \\
\hline Selling price of the dish, rub. & 24.68 \\
\hline
\end{tabular}

The data shown in table 8 indicate the economic feasibility of producing a drink. 


\section{Conclusions}

The results of the assessment of the nutritional and biological value make it possible to recommend this drink for implementation at public catering establishments, the developed technology and recipe make it possible to obtain a high quality product that meets the established requirements of the NTD.

\section{References}

1. Nutrition for the elderly, http://xn--4-9sb0a.xn--p1ai/med-profilaktika/pravilnoepitanie/? ELEMENT_ID = 485. - Access date: 01/08/2021.

2. E.A. Kruglova, Zh.A. Vlasova, Bulletin of scientific works of young scientists, graduate students, undergraduates of the Gorsky State Agrarian University, 57, 121123 (2020)

3. Zh.A. Vlasova, S.V. Akkatseva, Proceedings of Gorsky State Agrarian University, 58 (1), 107-110 (2021)

4. E.R. Gosteva, N.N. Kozlova, Proceedings of Gorsky State Agrarian University, 55 (2), 54-57 (2018)

5. V.V. Kulintsev, M.B. Ulimbashev, B.T. Abilov, Proceedings of Gorsky State Agrarian University, 54 (3), 62-65 (2017)

6. R.G. Kabisov, E.V. Ramonova, Proceedings of Gorsky State Agrarian University, 52 (1), 234-239 (2015)

7. B.G. Tzugkiev, R.G. Kabisov, A.G. Petrukovich, E.V. Ramonova, V.B. Tzugkieva, E.I. Rekhviashvili, Advances in Environmental Biology - Jordan (Amman-Jordan). American-Eurasian Network for Scientific Information (AENSI publisher), 8 (13), 335-340 (2014)

8. GOST 31450-2013, Drinking milk. Technical conditions, 11 (M.: Standartinform, 2019)

9. TR CU 021/2011, Technical Regulations of the Customs Union "On food safety". Introduce, 880, 242 (Minsk: Decision of the Commission of the Customs Union, 2011)

10. TR CU 033/2013, Technical Regulations of the Customs Union "On the safety of milk and dairy products.", 67, 129 (Minsk: Decision of the EEC Council, 2013)

11. GOST 33491-2015, Fermented milk products enriched with bifidobacteria bifidum. Technical conditions, 24 (M.: Standartinform, 2016)

12. GOST 31454-2012, Kefir. Technical conditions, 12 (M.: Standartinform, 2019) 